\title{
Chronic Toxicity of Paraquat on Liver and Gill Electrolyte in The Catfish ClariasGariepinus
}

\author{
Edori, $\mathrm{O} \mathrm{S}^{1}$; Edori, $\mathrm{E} \mathrm{S}^{2}$. And Okpara, K. E. ${ }^{3}$ \\ 1.Department of Chemistry, Ignatius Ajuru University of Education, PMB 5047 Rumuolumeni, Port Harcourt, \\ Nigeria \\ 2. Government Comprehensive Secondary School Mbiama, AhoadaWest,Rivers State Nigeria \\ 3.School Medical Laboratory Science, Rivers State College of Health Science and Technology, PMB 5049 \\ Rumueme, Port Harcourt, Nigeria
}

\begin{abstract}
The chronic effect of paraquat on the catfish Clariasgariepinus was assessed by comparing the changes in electrolytes in the organs (gills and liver) of a control group $(0.00 \mathrm{mg} / \mathrm{L})$ and toxicant exposed groups $(2.00 \mathrm{mg} / \mathrm{L}, 4.00 \mathrm{mg} / \mathrm{L}, 6.00 \mathrm{mg} / \mathrm{L}$ and $8.00 \mathrm{mg} / \mathrm{L})$. The levels of the electrolytes were determined on 20 fishes of $220.50 \pm 15.33 \mathrm{~g}$ mean weight and $30.43 \pm 1.22$ mean total length. The value of the chloride ions in the gills and the liver were significantly $(P>0.05)$ lower than the control value except at $8.00 \mathrm{ml} / \mathrm{L}$. The value of sodium ion in the gills showed increase in levels and was significant $(P>0.05)$ at $6.00 \mathrm{mg} / \mathrm{L}$ but the case was reverse in the liver where decrease in levels was observed in all the treatment groups. Significant $(P>0.05)$ higher values were observed in potassium levels in the treated groups in the gills when compared to the control values, while in the liver, no significant $(P>0.05)$ changes were observed. The result of this study shows that paraquat can cause marked changes in electrolytes levels of the fish and therefore can be used as a biomarker of aquatic pollution and toxicity.
\end{abstract}

Keywords: Paraquat, Electrolytes, Clariasgariepinus, Gills and Liver

\section{Introduction}

Countries with high temperatures and high humidity are always associated with weed and insect growth problems. In order to solve these attendant problems, the use of herbicides / insecticides are employed for their control to obtain maximum crop yield (Yuan et al., 2004). Pesticides are also used in aquaculture practices to control a great variety of pest and ectoparasites in fish( Das and Mukherjee, 2000; Kori-Siakpereet al., 2007). These agrochemicals whether applied directly on water to kill water weed or on farmlands have negative consequences on aquatic biota. Fish and other aquatic animals are very sensitive to aquatic pollution and shows both pathological and physiological alterations when exposed to these xenobiotics (Gabriel et al,.2010; Cecik and Engin 2005).

Though these pesticides may be applied in very low concentrations, yet these sublethal concentrations at the long run will prove to become dangerous (lethal) to organism(Yuan et al,. 2004) by altering the behaviour, feeding habit, reproduction rates, school groups (Murty,1986) and in severe cases may lead to death (Gabriel and Edori, 2010). The aquatic ecosystem is faced with the threat of shrinking genetic base and biodiversity resulting from indiscriminate use of pesticides (Benson and De-Giulio, 1992). Pesticides available in the aquatic environment get accumulated in the body tissues of aquatic species which eventually become integrated into the food chain (Omitoyinet al., 2006). As a result of residual effects, organs such as liver, kidney, gills, brain, muscles and genital organs are destroyed (Ogunsanmiet al,. 1994) or hindered from performing their biochemical functions optimally.

Paraquat (N, N- dimethyl- dimethyl-4,4- bipyridinium dichloride) is one of the most used herbicide in the world and it is highly toxic weed killer. It is second only to glyphosate in world wide application (Zeneca, 1996), it was first synthesized in 1882 but its application as a herbicide was not discovered until 1955 in the ICI (now Zeneca) laboratories and its commercial production started from 1961 (Zeneca 1996).

It causes severe, acute and chronic poisoning when it is water borne (Yuan et al., 2004) and readily dissolves and dissociates when in an aqueous media (Amduret al., 1991). Lungs selectively accumulate paraquat and contains higher concentration than tissue, causing oedema and other lungs damage leading to fibrosis. It also causes liver damage and renal failure as the kidney tries to remove absorbed paraquat (Dial and Dial, 1995).

This study was undertaken to examine the toxic effects of chronic (sublethal) levels of the toxicant (paraquat) on the electrolytes in the liver and gill of an important commercial fish specieClariasgariepinus.

\section{Materials And Methods}

Clariasgariepinus $(220.50 \pm 15.33 \mathrm{~g}$ mean weight and $30.43 \pm 1.22 \mathrm{~cm}$ mean total length) were bought from a private farm in Port Harcourt close to the university of Port Harcourt in Rivers State Nigeria. They were 
transported to the Chemistry department laboratory of the Ignatius Ajuru University of Education, Port Harcourt. The fishes were acclimated to laboratory conditions in individual tanks for seven days with bore hole water with 10 litre effective volume in a 30 litre plastic aquaria. The mouth of the aquaria were covered with $1 \mathrm{~mm}$ nylon mesh to prevent escape of fish from the aquaria. The fish were fed with $31-35 \%$ crude protein diet at $2 \%$ biomass during the acclimation and the experimental period.

Completely randomized design was used in the experiment with five treatment levels and four replicates. The test solutions were prepared from a stock of $20 \mathrm{~g} / 1$ and was diluted to the desired concentration and a control. Fishes were fed during the experimental period as was in the acclimation. The solution for the assay was renewed daily to maintain the concentrations. At the end of the experimental period (21 days), the fishes were killed by striking a blow on the head and dissected to remove the liver and the gills. $0.5 \mathrm{~g}$ of the samples (gills and liver) were macerated and mixed with $5 \mathrm{ml}$ of deionized water and centrifuged at $3000 \mathrm{rpm}$ for ten minutes. The supernatant was transferred into plain bottles and stored frozen $\left(-2^{\circ} \mathrm{C}\right)$

The samples were taken to the laboratory for electrolytes analysis. Sodium (Na), potassium $(\mathrm{K})$ and chloride $(\mathrm{Cl})$ ions concentrations were determined using the automatic analyzer and optimal test by means of flame photometry as was described by Schales and Schales, (1941). The concentrations of the various electrolytes were expressed as $\mathrm{mmol} / \mathrm{L}$. The data obtained were subjected to analysis of variance (ANOVA) to determine if significant differences existed between the means in the parameters at different levels of contamination. Where differences existed, Duncan's Multiple range test (DMRT) was used to compare the difference between the means.

\section{Results}

In the gills, chloride ions were lower in all the test concentrations except at the highest concentration which was $126.50 \pm 3.00 \mathrm{mmol} / \mathrm{L}$ as against the control value of $117.00 \mathrm{mmol} / \mathrm{L}$. The lowest level of chloride was observed at $2.00 \mathrm{~g} / \mathrm{L}$ which was $33.00 \pm 0.90 \mathrm{mmol} / \mathrm{L}$. However, sodium ions increased in all the concentrations above that of the control $(343.50 \pm 3.06 \mathrm{mmol} / \mathrm{L})$. The highest recorded value of $500.00 \pm 13.44$ $\mathrm{mmol} / \mathrm{L}$ was recorded at $6.00 \mathrm{mg} / \mathrm{L}$ concentration followed by that of $4.00 \mathrm{mg} / \mathrm{L}(390.00 \pm 6.40 \mathrm{mmol} / \mathrm{L})$ and $8.00 \mathrm{mg} / \mathrm{L}(375.00 \pm 8.13 \mathrm{mmol} / \mathrm{L})$. There was an observed decreased levels of potassium ions at $6.00 \mathrm{mg} / \mathrm{L}$ which was $22.27 \pm 0.75 \mathrm{mmol} / \mathrm{L}$ as against the control value of $24.20 \pm 0.97 \mathrm{mmol} / \mathrm{L}$. There were noted increase in all other concentrations which were $30.80 \pm 3.31 \mathrm{mmol} / \mathrm{L}, 31.21 \pm 0.19 \mathrm{mmol} / \mathrm{L}$ and $38.07 \pm 5.55 \mathrm{mmol} / \mathrm{L}$ for $2.00 \mathrm{mg} / \mathrm{L}, 4.00 \mathrm{mg} / \mathrm{L}$ and $8.00 \mathrm{mg} / \mathrm{L}$ respectively.

In the liver, decrease in levels of the chloride ion was observed in all the test concentrations. The value of $140.00 \pm 8.21 \mathrm{mmol} / \mathrm{L}$ was observed in the control followed by that of $6.00 \mathrm{mg} / 1$ which was $136.5 \pm$ $4.37 \mathrm{mmol} / \mathrm{L}$. The lowest value of $48.66 \pm 2.80 \mathrm{mmol} / \mathrm{L}$ was recorded at $4.00 \mathrm{mg} / \mathrm{L}$ test concentration. The levels of sodium ions were all slightly lower than that of the control (330.59 \pm 4.52$)$. Other values were $320.67 \pm 0.35$ $(4.00 \mathrm{mg} / \mathrm{L}), 311.00 \pm 13.49 \mathrm{mmol} / \mathrm{L}(8.00 \mathrm{mg} / \mathrm{L})$ and $302.00 \pm 10.72 \mathrm{~mol} / \mathrm{L}$. The lowest value of $298.00 \pm$ $5.03 \mathrm{mmol} / \mathrm{L}$ was observed at $2.00 \mathrm{mg} / \mathrm{L}$. Potassium ions were in the range of $32.73 \pm 1.52 \mathrm{mmol} / \mathrm{L}(2.00 \mathrm{mg} / \mathrm{L})$ as the highest to $25.91 \pm 0.57 \mathrm{mmol} / \mathrm{L}(6.00 \mathrm{MG} / \mathrm{L})$ the lowest level as against the control value of $29.66 \pm$ $1.30 \mathrm{mmol} / \mathrm{L}$.

\section{Discussion}

Electrolytes are ions in solution which acquire the capacity to conduct electricity and their balance in the body of organism is essential for the normal function of cells and organs. According to Harper (1977) and Gabrielet al,. (2009), the basic functionof electrolytes in the body lies in the control of fluid distribution, intracellular and extracellular acido-basic equilibrium which culminates in the proper maintenance of osmotic pressure of body fluids and normal neuro-muscular irritability.

Chloride is the major anion found in the outside of the cell and the blood. It combines with sodium in the body to form sodium chloride $(\mathrm{NaCl})$ and plays the role of helping the body to maintain normal fluid balance (Gabriel et al., 2009). The observed decrease in this ion in the fish organs (gills and liver) may have resulted from a dehydration process in the fish and stomach (intestinal) secretions (Tomassoet al., 1980). However, stomach diseases, over reactivity of the parathyroid glands and certain kidney diseases leads to increase of this ion in organism (Gabriel et al., 2009).

Sodium ion is the major ion (cation) in the extracellular fluid. Sodium plays a critical role in body functions. The brain, nervous system and muscle require the transmission of electrical signals for the organisms communication. The implication of the overproduction and underproduction can lead to cell malfunctioning and also indicates damage to the gills and the kidney (Rajannaet al., 1981). However, a little increase in this ion $(\mathrm{Na}+)$ is an indication of improvement of kidney function. Decrease in levels of sodium ion $(\mathrm{Na}+)$ affects the heart functions of the organism and a neurotoxic damage to the central nervous system of the organism under test (Adedeji, 2010).। 
Potassium ion $\left(\mathrm{K}^{+}\right)$is the major positive ion in the intracellular fluid and is essential for normalcell function and body regulation. The observed increase and decrease in potassium $\left(\mathrm{K}^{+}\right)$ion in this study is as a result of the interference of the toxicant with normal organ function of the gill and liver. An increase or decrease in potassium $\left(\mathrm{K}^{+}\right)$ion normally results in irregular heartbeats (arrhytamias) which can be fatal in extreme conditions (Gabriel et al., 2009).

Sodium and potassium are essential for the activity of many enzymes and are involved in ATP transport which participates in several metabolic processes. $\mathrm{Na}^{+}$and $\mathrm{K}^{+}$ATPases are located in the membranes of cells and are responsible in the active transport of $\mathrm{Na}^{+}$and $\mathrm{K}^{+}$across cell membrane (Rajannaet al., 1981).

Generally, the imbalance electrolytes in fish causes lateral line imbalance and hormonal disorder through affective endocrine organs through attack by pesticides (Tella, 2005; Gabriel et al., 2009).

The changes observed in the electrolytes in the fish organs (gills and liver) may have been caused by deleterious effects posed by paraquat toxicity.

\section{References}

[1]. Adedeji, O. B. (2010). Acute effects of diazinon on blood plasma biochemistry in the African catfish (Claris gariepinus). Journal of Clinical Medicine and Research, 2(11): 1-6.

[2]. Amdur,M. O., Doull, J. and Klaassen,C. D. (1991). Toxicology: the basic science of toxins. $4^{\text {th }}$ ed. Pergamon Press, New York. 602-603.

[3]. Benson, W. H. and Di-Giulio, R. T. (1992).Biomarkers in hazard assessment of contaminated sediments. In: sediments toxicity assessment, G. A. Burton(ed), Lewis Boca Raton, 241-256.

[4]. Cecik, B. and Engin, K. (2005). The effects of cadmium on levels of glucose in serum and glycogen reserves in the liver and muscle tissues of Cyprinuscarpio. Turk. J. Vet. Anim. Sci. 29:113-117.

[5]. Das, B. K. and Mukherjee, S. C. (2000). Sublethal effects of quinalphos on selected blood parameters of Labeorohita(Ham) fingerlings. Asian Fish Sci. 13: 225-233.

[6]. Dial, B. C. A. and Dial, N. A. (1995). Lethal effects of the consumption of field levels of paraquat-contaminated plants on frog tadpoles .Bull. Environ. Contam. Toxicol. 55: 870-877.

[7]. Gabriel, U. U. and Edori O. S. (2010). Mortality and behavioural responses of Clariasgariepinus and its hybrid to acute levels of dichlobenil. 11(1):74- 81.

[8]. Gabriel, U. U., Obomanu, F. G. and Edori O. S. (2010). Biochemical changes in hybrid catfish(Heterobranchusbidorsalis $\times$ Clariasgariepinus) treated with nuracron. Chinese J. Appl.Environ. Biol. 16(3):353-357.

[9]. Jolorn

[10]. Gabriel, U. U., Jack I. R., Edori, O. S. and Egobueze, E. (2009). Electrolytes in selected tissues of Heterobranchusbidorsalistreated with sublethal levels of Cypermethrin. Ethiopian Journal of Environmental Studies and Management. 2(3):83-87.

[11]. Harper, H. A.(1977).Pfiehledfysiologickechemieavicenum, Praha. P 639.

[12]. Kori-Siakpere, O., Adamu, K. and Achakpokiri, J. A. (2007). Sublethal effects of paraquat on plasma glucose levels and glycogen reserves in liver and muscle tissues of African catfish (Clariasgariepinus) under laboratory conditions. Journal of Fisheries and Aqautic Sciences, 2(3): 242-247.

[13]. Murty, A. S. (1986). Toxicity of pesticides to fish (Vol. ii). CRC Press.Boca Raton FL.

[14]. Ogunsanmi, A. O.,Akpavie, S. O. and Anosa, V.O. (1994). Serum biochemistry changes

[15]. In West African dwarf sheep experimentally infected with T. brucei .Rev. Elec. Med Vet. Pays Trop. 47:195-200.

[16]. Omitoyin, B.O., Ajani, E. K., Adesina, B. T. and Okuagu,C. N. F. (2006). Toxicity of lindane (gamma hexachlorocyclohexane) to Clariasgariepinus (Buurchel,1822). World Journal Zoology, 1(1): 57-63.

[17]. Rajanna, B., Chapatwala, K. D., Vaishnav, D. D. and Desaiah, D. (1981). Changes in ATphase activity in tissues of rat fed on cadmium. J. Environ. Biol. 2(1): 1-9.

[18]. Schales, O. and Schales, S. S. (1991). A simple and accurate method for the determination of chloride ion in biological fluid. $J$. Biol. Chem. 140:879-884.

[19]. Talla, M. A.(2005). Serum electrolyte changes in West African dwarf (WAD) sheep with single or concurrent (Bebesiaovis andTympanosome Congolese) infections. African Journal of Biological Research, 8: 63-65.

[20]. Tommasso, J. R., Davis, K. B. and Parker, N. C. (1980). Plasma corticosteroid and electrolyte dynamics of hybrid striped bass (white bass $\times$ striped bass) during netting and hauling. Proc. World Maricutt. Soc. 1: 303-310.

[21]. Yuan,V. C., Chen, H. C. and Yuan, Y.K. (2004). Sublethal effects of paraquat and malathion on the fresh water shrimp, Macrobrachiumnipponense.I, 14(2): 87-95.

[22]. Zeneca (1996). To boost herbicides. Financial times.

Table 1. $\mathrm{Cl}^{-}, \mathrm{Na}^{+}$and $\mathrm{K}^{+}$in the gills of Clariasgariepinus exposed to paraquat for 21 days.

\begin{tabular}{|l|l|l|l|}
\hline $\begin{array}{l}\text { Concentration of } \\
\text { paraquat }(\mathrm{mg} / \mathrm{L})\end{array}$ & $\mathrm{Cl}^{-}(\mathrm{mmol} / \mathrm{L})$ & $\mathrm{Na}^{+}(\mathrm{mmol} / \mathrm{L})$ & $\mathrm{K}^{+}(\mathrm{mmol} / \mathrm{L})$ \\
\hline 0.00 & $117.00 \pm 14.48^{\mathrm{a}}$ & $343.50 \pm 3.06^{\mathrm{ab}}$ & $24.20 \pm 0.97^{\mathrm{b}}$ \\
\hline 2.00 & $33.00 \pm 0.90^{\mathrm{d}}$ & $348.50 \pm 10.39^{\mathrm{ab}}$ & $30.80 \pm 3.30^{\mathrm{ab}}$ \\
\hline 4.00 & $93.33 \pm 7.49^{\mathrm{b}}$ & $390.00 \pm 6.40^{\mathrm{ab}}$ & $31.21 \pm 0.19^{\mathrm{ab}}$ \\
\hline 6.00 & $63.00 \pm 3.82^{\mathrm{c}}$ & $500.00 \pm 13.44^{\mathrm{a}}$ & $22.27 \pm 0.75^{\mathrm{b}}$ \\
\hline 8.00 & $126.00 \pm 3.00^{\mathrm{a}}$ & $375.00 \pm 8.13^{\mathrm{ab}}$ & $38.07 \pm 0.55^{\mathrm{a}}$ \\
\hline
\end{tabular}

Means with the same superscript in the same column are not significantlyDifferent $(\mathrm{P}>0.05)$ 
Table 2. $\mathrm{Cl}^{-}, \mathrm{Na}^{+}$and $\mathrm{K}^{+}$in the liver of Clariasgariepinus exposed to paraquat for 21 days.

\begin{tabular}{|l|l|l|l|}
\hline $\begin{array}{l}\text { Concentration } \\
\text { paraquat }(\mathrm{mg} / \mathrm{L})\end{array}$ & $\mathrm{Cl}^{-}(\mathrm{mmol} / \mathrm{L})$ & $\mathrm{Na}^{+}(\mathrm{mmol} / \mathrm{L})$ & $\mathrm{K}^{+}(\mathrm{mmol} / \mathrm{L})$ \\
\hline 0.00 & $140.00 \pm 8.21^{\mathrm{a}}$ & $330.50 \pm 4.52^{\mathrm{a}}$ & $29.66 \pm 1.30^{\mathrm{a}}$ \\
\hline 2.00 & $63.50 \pm 3.00^{\mathrm{c}}$ & $298.00 \pm 5.03^{\mathrm{a}}$ & $32.73 \pm 1.52^{\mathrm{a}}$ \\
\hline 4.00 & $48.66 \pm 2.80^{\mathrm{c}}$ & $320.67 \pm 10.35^{\mathrm{a}}$ & $29.22 \pm 0.50 \mathrm{a}$ \\
\hline 6.00 & $136.50 \pm 37^{\mathrm{a}}$ & $302.50 \pm 10.72^{\mathrm{a}}$ & $25.91 \pm 0.75^{\mathrm{a}}$ \\
\hline 8.00 & $106.50 \pm 7.66^{\mathrm{b}}$ & $311.00 \pm 13.49^{\mathrm{a}}$ & $28.98 \pm 1.95^{\mathrm{a}}$ \\
\hline
\end{tabular}

Means with the same superscript in the same column are not significantly differently $(\mathrm{P}>0.05)$

Table 3: Percentage of control of $\mathrm{Cl}^{-}, \mathrm{Na}^{+}$and $\mathrm{K}^{+}$in the glls of Clariasgariepinus exposed to paraquat for 21 days.

\begin{tabular}{|l|l|l|l|}
\hline $\begin{array}{l}\text { Concentration } \\
\text { paraquat(mg/L) }\end{array}$ & $\mathrm{Cl}^{-}$ & $\mathrm{Na}^{+}$ \\
\hline 0.00 & 100 & 100 & 100 \\
\hline 2.00 & $28.21(-71.79)$ & $101.46(1.46)$ & $127.27(27.27)$ \\
\hline 4.00 & $79.77(-20.23)$ & $113.56(13.56)$ & $128.97(28.97)$ \\
\hline 6.00 & $53.85(-46.15)$ & $145.56(45.56)$ & $92.02(-$ \\
\hline 8.00 & $107.69(7.69)$ & $109.17(9.17)$ & $157.31(57.31)$ \\
\hline
\end{tabular}

Negative sign in the table shows the level of decrease while positive sign shows the level of increase as against the control.

Table 4: Percentage of control of $\mathrm{Cl}^{-}, \mathrm{Na}^{+}$and $\mathrm{K}^{+}$in the liver of Clariasgariepinus exposed to paraquat for 21 days.

\begin{tabular}{|l|c|c|c|}
\hline $\begin{array}{l}\text { Concentration } \\
\text { paraquat(mg/L) }\end{array}$ & \multicolumn{1}{l|}{$\mathrm{Cl}^{-}$} & $\mathrm{Na}^{+}$ \\
\hline 0.00 & 100 & 100 & 100 \\
\hline 2.00 & $45.36(-54.64)$ & $90.17(-9.83)$ & $110.35(10.35)$ \\
\hline 4.00 & $34.76(-65.24)$ & $97.03(-2.97)$ & $98.52(-1.48)$ \\
\hline 6.00 & $97.50(-2.50)$ & $91.52(-8.47)$ & $87.36(-12.64)$ \\
\hline 8.00 & $76.07(-23.93)$ & $94.10(-5.9)$ & $97.71(-2.29)$ \\
\hline
\end{tabular}

Negative sign in the table shows the level of decrease while positive sign shows the level of increase as against the control. 